\title{
MUNICIPAL SOLID WASTE MANAGEMENT IN THE AMAZON: ENVIRONMENTAL, SOCIAL, AND ECONOMIC PROBLEMS, GAPS, AND CHALLENGES
}

\author{
BENONE OTÁVIO SOUZA DE OLIVEIRA ${ }^{1,2}$ \& GERSON ARAUJO DE MEDEIROS ${ }^{2}$ \\ ${ }^{1}$ Federal University of Amazonas (UFAM), Campus Vale do Rio Madeira, Brazil \\ ${ }^{2}$ State University of São Paulo (UNESP), Sorocaba, Brazil
}

\begin{abstract}
The Amazon region presents challenges for the management of municipal solid waste (MSW), due to its social, environmental, and economic vulnerabilities. This work investigated MSW management in the Amazon and in the Southwest Brazilian Amazon (SWBRAM). A bibliographic search (from 2007 to 2019) was performed for articles published in scientific journals and in official reports, related to MSW management in the countries of the Amazon. Visits in loco to the Brazilian municipalities of Humaitá and Manicoré, in Amazonas State (AM), and Ariquemes, in Rondônia State (RO), gathered information about the characteristics of MSW (Humaita), the conditions of a waste-collection cooperative (Manicoré), and the management of a sanitary landfill (Ariquemes). The bibliographic search found only sixteen articles, highlighting the following aspects of MSW management in the Amazon: high organic-matter content (50\%) and low MSW generation. There was significant disposal of waste in dumps, an incipient recycling market, and a lack of infrastructure for logistics. The MSW management scenario for the SWBRAM was similar to that for the Amazon. In Humaitá, MSW was deposited in a dump, leading to the presence of waste pickers. In Manicoré, only plastic, paper, and aluminum could feasibly be transported on the Madeira River to the recycling industry in Manaus (AM). The high rainfall and the distance to transport MSW were the main issues related to landfill management in Ariquemes. Management actions proposed in the literature present limitations in the Amazon environment, so there is the need for continuous investment in MSW prevention programs and treatment technologies, besides optimizing recycling and composting.
\end{abstract}

Keywords: sanitary landfill, recycling, waste picker, dump.

\section{INTRODUCTION}

Economic development associated with fast industrialization, urbanization, and population growth has intensified the rate of generation of municipal solid waste (MSW), including wastes from households, urban cleaning, and the commercial sector [1]. Consequently, MSW managers are faced with the challenge of reducing the risks of damage to the environment and human health, especially in developing countries.

Factors contributing to the intensification of environmental degradation include inadequate MSW management, lack of urban planning, shortage of qualified workers, insufficient information, financial restrictions, and other factors [2].

In Brazil, Law $\mathrm{n}^{\circ}$ 12,305, National Policies on Solid Wastes (NPSW), regulates MSW management, providing guidelines that prioritize the prevention and minimization of waste generation, as well as concerning the reutilization, recycling, recovery (including energetic), and elimination (incineration or landfill disposal) of waste [2]. But the reality and contrasting diversity of a continental-size country like Brazil hampers the adoption of MSW management systems such as those proposed in the NPSW and employed in developed countries.

In this context, the Amazon is characterized by environmental, social, and economic vulnerabilities. Therefore, the main goal of this research was to identify municipal solid wastes management strategies in the Amazon, as well as to undertake an assessment in the 
SWBRAM, seeking to identify the gaps and challenges concerning this issue, as well as suggest possible improvement strategies for the locations studied.

\section{CHARACTERISTICS OF THE MUNICIPALITIES IN THE AMAZON AND SWBRAM}

The Amazon region covers an area of approximately 7.5 million $\mathrm{km}^{2}$, or $7 \%$ of the total surface of the Earth [3]. It corresponds to $40 \%$ of the area of South America and $58 \%$ of the sum of the areas of the countries in which it is present: Bolivia, Brazil, Colombia, Ecuador, Guyana, French Guiana, Peru, Suriname, and Venezuela.

Guyana, French Guiana, and Suriname have $100 \%$ of their areas located in the Amazon, while Venezuela presents the smallest relative area in the Amazon region (approximately $20 \%$ of its territory). Brazil has the largest absolute Amazon area among all the countries with territory in the Amazon (5.0 million $\mathrm{km}^{2}$, or $67 \%$ of the total area), with contributions from nine states: Acre (AC), Amapá (AP), Amazonas (AM), Pará (PA), Rondônia (RO), Roraima (RR), Tocantins (TO), Mato Grosso (MT), and Maranhão (MA).

Despite its vast area, the Amazon population was estimated at 28 million inhabitants, or only $8 \%$ of the sum of the populations of these nine countries [4], with Brazil presenting the highest number of people living in this region (24 million people).

The climate of the region is Humid Equatorial, with annual average temperature varying from $26^{\circ} \mathrm{C}$ to $28^{\circ} \mathrm{C}$ and with rainfall exceeding 2,000 mm per year [3]. Fig. 1 shows the Amazon region, highlighting the SWBRAM.

The municipality of Humaitá (AM) is located in the SWBRAM (07 30' $22^{\prime \prime}$ S; $63^{\circ} 01^{\prime} 15^{\prime}$, W; 90 m a.s.l.), on the banks of the Madeira River (an affluent of the Amazon River), $700 \mathrm{~km}$

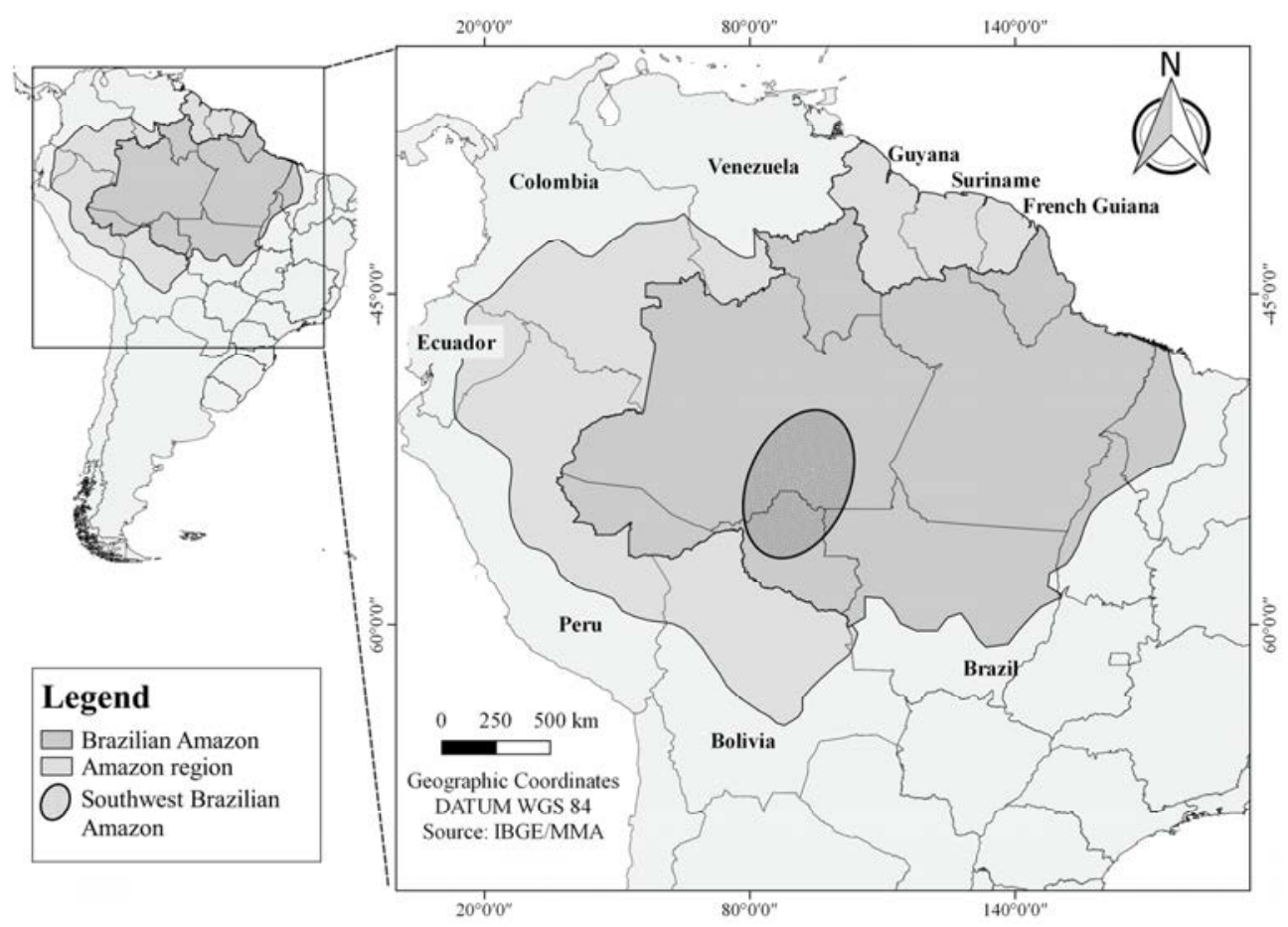

Figure 1: Amazon extension, highlighting the Southwest Brazilian Amazon. 
from Manaus, the Amazonas State capital. In the dry season, there is the possibility of accessing Humaitá by land (highway BR-319), while only transport on the Madeira River is viable in the rainy season. Humaitá has approximately 54,000 inhabitants, a population density of 1.34 inhab. $\mathrm{km}^{-2}$, and a per capita gross domestic product (GDP) of US\$ 2,200.00 [5].

The municipality of Manicore (AM) $\left(05^{\circ} 48^{\prime} 33^{\prime \prime} \mathrm{S}\right.$; $61^{\circ} 18^{\prime} 01^{\prime \prime} \mathrm{W}$; $45 \mathrm{~m}$ a.s.l.) is $390 \mathrm{~km}$ distant from Manaus, with access only possible on the Madeira River. The municipality shares a land border with Humaitá and has the only waste collector cooperative in the SWBRAM. It has 54,900 inhabitants, corresponding to a population density of 0.97 inhab. $\mathrm{km}^{-2}$, and per capita GDP of US\$2,330.00 [6].

Ariquemes $\left(09^{\circ} 54^{\prime} 17^{\prime}, \mathrm{S} ; 63^{\circ} 02^{\prime} 58^{\prime \prime} \mathrm{W} ; 142 \mathrm{~m}\right.$ a.s.1.) is a municipality $200 \mathrm{~km}$ distant from the Rondônia State capital Porto Velho, and $400 \mathrm{~km}$ from Humaitá, being connected to both by the BR 364 highway. The population of this municipality is estimated at 106,168 inhabitants, corresponding to a population density of 20.41 inhab. $\mathrm{km}^{-2}$, and the per capita GDP is US\$ 4,900.00 [7]. Ariquemes possesses the only sanitary landfill within a radius of $500 \mathrm{~km}$ from Humaitá.

\section{MATERIAL AND METHODS}

\subsection{Review of the management of municipal solid wastes in the Amazon}

The review of MSW management in the Amazon considered the period from 2007 to 2019 and employed the Web of Science, Google Scholar, and Scopus databases, together with cross-citations. The keywords used were "municipal solid waste", "Amazon", and "Brazil", in English, Spanish, and Portuguese versions, together with the Boolean connectors "AND", in order to link one keyword to another, and "OR", to enable the search to access works that had any of the keywords. Information from official agencies of the Amazon countries was also accessed.

\subsection{Diagnosis of MSW management in the Southwest Brazilian Amazon}

In Humaitá, investigation was made of MSW management practices, together with characterization of the MSW that had been collected without any selection and disposed of in the dump area, since 1995.

In the municipalities of Manicore and Ariquemes, in loco visits were made, with photographic recording, visual evaluation, and information collection. In Manicoré, a visit was made to the Recyclable Material Collectors Cooperative, during the period from April 30th to May 3rd, 2018, to study the potential and limitations of the collection and commercialization of waste materials by the only formal cooperative of recyclable material collectors in the Southwest Brazilian Amazon.

A technical visit to the Ariquemes municipal landfill, during the period from May 8th to 9th, 2018, was conducted in order to understand its potential and limitations, in the Amazon context. This landfill was the closest one to the municipality of Humaitá.

\section{RESULTS AND DISCUSSION}

\subsection{Solid waste management in the Amazon}

Sixteen articles relevant to the topic were published in scientific journals, from 2007 to 2019 , revealing the scarcity of research about MSW management in this geographic region. Only three countries of the Amazon produced articles listed in the international databases 
employed. Of these, Brazil produced twelve articles [2], [8]-[18], while two articles each was produced by Colombia [19], [20] and Peru [21], [22].

The articles presented proposals and diagnostics related to MSW management in the Amazon, considering aspects such as energy production [11], [13], technological issues and selective collection limitations, and reverse logistics and recycling [8], [12], [14], [15], [20]. Discussion was also provided of environmental, social, economic, and legal implications of the disposal of MSW in dumps and sanitary landfills [2], [8], [9], [12], [14]-[17], [20], [21], environmental management [2], [10], and governance [18], [19], [22].

One important aspect was the low population density in the Amazon [17], which could explain the scarcity of articles from the countries that compose it. For the countries (Suriname and Guyana) and territory (French Guiana) totally inserted in the Amazon, no articles published in scientific journals were found, within the period considered.

The bibliographic search results were complemented by the reports of official organs of the countries of this region. These organs were the Ministry of Cities in Brazil (MCIDADES) [23], the Ministry of Environment and Water in Bolivia (MMAyA) [24], the National Council of Economic and Social Policies in Colombia (SSPD) [25], the National Institute of Statistics and Census in Ecuador (INEC) [26], the Ministry of Local Government and Regional Development in Guyana (MLGRD) [27], the Ministry of Environment in Peru (MINAM) [28], and the National Institute of Statistics in Venezuela (INE) [29]. No information was found related to official organs of Suriname and French Guiana.

Table 1 presents the results of information compiled from these documents. The scarce information about MSW management in Suriname was obtained from reports of the Inter-American Development Bank (IDB) [30].

Table 1: Information compiled from official reports concerning solid wastes in the countries that form the Amazon.

\begin{tabular}{|l|c|c|c|c|c|c|}
\hline Country & Landfill & Dump & Gen. Amaz. & Recycled & PPC & PPC Amazon \\
\hline & \multicolumn{5}{|c|}{$\%$} & \multicolumn{2}{c|}{$\mathrm{kg}$ (inhab.day) $)^{-1}$} \\
\hline Brazil [23] & 59 & 20 & 5.4 & 3.4 & 0.94 & 0.99 \\
\hline Bolivia [24] & 45 & 22 & 6.8 & 3.7 & 0.46 & 0.43 \\
\hline Colombia [25] & 83 & NI & NI & 1.8 & 0.78 & NI \\
\hline Ecuador [26] & 42 & 41 & 3.4 & 0.6 & 0.58 & 0.57 \\
\hline Guyana [27] & 61 & 39 & 100 & 0.5 & 0.66 & 0.66 \\
\hline Peru [28] & 44 & 56 & 8.9 & 0.2 & 0.66 & 0.45 \\
\hline Venezuela [29] & NI & NI & 0.4 & 3.9 & 0.90 & 0.52 \\
\hline
\end{tabular}

Landfill: MSW percentage generated in the country and disposed of in landfills; Dump: MSW percentage generated in the country and disposed of in open-sky dumps and controlled landfills; Gen. Amaz.: MSW percentage generated in the Amazon region of the country; Recycled: MSW percentage recycled in the country; PPC: MSW daily production per capita; PPC Amazon: MSW daily production per capita in the Amazon region of the country.

The results indicated a significant disposal of MSW in dumps and controlled landfills, considered in this work as unsuitable methods of waste disposal.

Limitations on MSW management are imposed by the low Amazon population and factors such as climate conditions, difficulty in establishing sanitary landfills and reverse logistics, and the lack of markets for recycled material. For these reasons, landfills, recycling organizations, and companies responsible for the transport and disposal of MSW were concentrated in the metropolitan areas [2].

In the Peruvian Amazon, only two landfills were reported [28], which corresponded to $9.5 \%$ of those operating in the country. It should be noted that the main problems in MSW 
management are the lack of places that meet the requirements for the final disposal of the waste, cultural issues, poor infrastructure, and absence of public policies [31]. In the face of environmental problems, the National Environmental Council of Peru developed and approved the National Solid Wastes Integral Management Plan, which established guidelines, strategies, and activities aiming at improving MSW management. The strategies include recycling and suitable methods for the disposal of MSW in its entirety, in addition to the necessary investments and information [28].

In Guyana, there was single landfill located in the metropolitan region of the capital, Georgetown, which received around $60 \%$ of the MSW generated in the country [27].

In the Bolivian Amazon, there were no sanitary landfills and the wastes were disposed of in dumps [24]. The same applied to Suriname [30].

Regarding the wastes with recoverable value in the Bolivian Amazon, there were no facilities or technologies for the addition of value to recyclable materials or for the treatment of hazardous wastes [24].

In Venezuela, the poor management of solid wastes was evidenced by the following factors: inefficient collection, burning and incorrect handling of MSW final disposal, lack of public policies, and unsustainable generation of MSW [29].

The low population percentages living in the Amazon region were reflected in the amounts of solid waste generated, with the countries producing between $0.4 \%$ and $8.9 \%$ of their total MSW in this region (excluding the countries totally inserted in the Amazon). This has partly contributed to hampering the implementation of expensive civil construction works, such as sanitary landfills, as well as the structuring of the recycling industry and the circular economy.

Little specific information was found about recycling in the Amazon, except for Guyana, which recycled around $240 \mathrm{t} \mathrm{month}^{-1}$ of paper and cardboard, with $80 \mathrm{t} \mathrm{month}^{-1}(33 \%)$ being generated in the country itself, while $160 \mathrm{t} \mathrm{month}^{-1}(66 \%)$ was imported from Suriname and Trinidad and Tobago [27].

The per capita generation of solid wastes in the Amazon was lower than the average for each country, except for Brazil. In some countries, such as Bolivia, a significant part of the population lives in rural areas, where solid waste generation has been estimated at $0.20 \mathrm{~kg}$ (inhab.day) $^{-1}[24]$.

In Brazil, only around eighteen sanitary landfills $(2.5 \%$ of the total) were found in the Amazon [18]. In 2016, 36\% of the municipalities of this region were found to dispose of solid wastes in dumps or controlled landfills, while only $3.8 \%$ used sanitary landfills, which were mostly located in the capitals of the states [23]. However, the other $60.2 \%$ of the municipalities in the Brazilian Amazon have not either provided or updated the data in the National Information System on Basic Sanitation (NISBS), from which it may be inferred that the percentage of municipalities disposing of MSW in dumps could be higher than reported in official documents. The nine states of the Brazilian Amazon had 63 cooperatives, which corresponded to only $5 \%$ of the total of 1,177 registered in the NISBS [23].

Given the issues discussed above, it can be seen that a series of actions are needed for strengthening of the recycling chain in the Brazilian Amazon, including the installation of recycling companies, the strengthening of the cooperatives, and the implementation of reverse logistics, as proposed in the NPSW.

The low population densities, vast areas, bad road conditions, and prevalence of river transport hinder the implementation of reverse logistics and support for solid waste management in all the countries of the Amazon [8], [12], [14], [22]. Climatic factors such as high rainfall, besides making road transport difficult, hinder the selection of areas for installation of landfills and increase the negative environmental impacts of MSW disposal in dumps [2], [9], [14], [22]. 


\subsection{MSW management in the Southwest Brazilian Amazon}

\subsubsection{Overview for the municipality of Humaitá (AM)}

The steps of MSW management in Humaitá comprised the collection, transport, and disposal of the waste in a dump [32]. The collection, performed by an outsourced company, encompassed all types of solid wastes, both domestic and commercial, including rubble and gardening wastes. Sewage sludge from households has also been deposited in the dump.

The dump was $10 \mathrm{~km}$ from the city, at the edge of the BR 319 highway connecting Humaitá to Porto Velho (RO). Within a radius of $2 \mathrm{~km}$ from the dump, there was a higher education institution (Instituto Federal do Amazonas), a housing complex of 500 houses, and an airport (which was closed, due to the risk of accidents involving birds from the dump).

In the dump, there were collectors of recyclable waste (paper, plastic, and cardboard), who worked without any type of personal protection. After a first collection of wastes at the surface, they set fires to facilitate the collection of other materials (aluminum and ferrous metal) (Fig. 2).

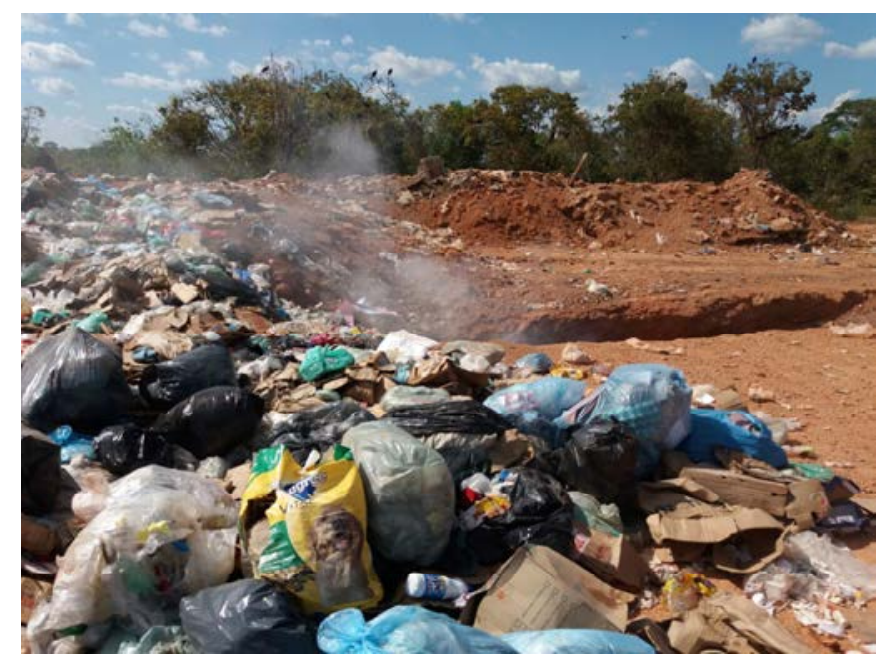

Figure 2: Municipal solid waste burning at the Humaitá dump in the Brazilian Amazon.

During the rainy season, the place was flooded and the slurry infiltrated the soil or drained over the surface, reaching water bodies $130 \mathrm{~m}$ distant from the dump [32].

There was no structured selective collection in Humaitá, although the waste pickers sold the recyclable material to an intermediary, who transported it for marketing in Porto Velho.

Guimarães [32] estimated that this municipality generated $11.2 \mathrm{t} \mathrm{day}^{-1}$ of MSW $(0.41 \mathrm{~kg}$ day $^{-1}$ per inhabitant), consisting of $47 \%$ organic matter, $40 \%$ recyclable waste (paper, plastic, metals, long-life packaging, and glass), and $13 \%$ other non-recyclable materials. The high content of organic matter (from $40 \%$ to $50 \%$ ) and the generation per capita were close to the values reported for other Amazon regions in Bolivia [24], Peru [28], and Venezuela [29].

\subsubsection{Overview of the collection of recyclable material in the municipality of Manicoré (AM)}

The municipality of Manicoré also deposited its MSW in a dump. However, this was the only municipality in the Southwest Brazilian Amazon that had an official waste-collectors 
cooperative, with 25 members [23]. Its creation was supported by the Secretariat of the Environment of Manicoré, in 2010.

This type of association promotes the recycling chain and contributes to social inclusion, reduction of environmental impacts, and smaller volumes of MSW disposed of in sanitary landfills, controlled landfills, or dumps [1].

The MSW sorting process was performed manually, with the plastic, paper, and aluminum being sent by boat to the city of Manaus, $390 \mathrm{~km}$ distant, without compaction, since the cooperative did not possess a mechanical press (Fig. 3).

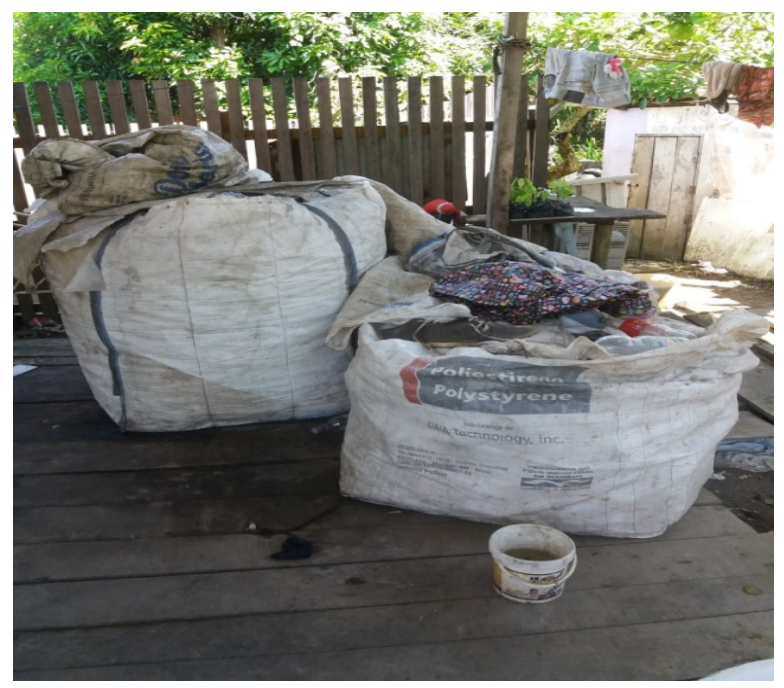

Figure 3: Recyclable materials from the waste collector cooperative in Manicoré, Brazil.

The waste transport time could be up to 30 hours by boat, or $60-90$ hours by ferry, depending on the sailing conditions on the Madeira River. Considering these conditions, the cooperative sent the material (2.5-3.5 t) on a monthly basis, by boat, at a cost of US\$ 30.00 per ton.

Despite the distance, Manaus is the closest city to Manicore and has an industrial recycling sector. However, there are no specific recycling industries for glass, long-life packaging, and ferrous metals, so these materials have low commercial value, invalidating the transport cost.

It could be seen that the cooperative did not have the necessary resources to collect and separate the MSW, although a partnership with the municipal energy supplier would be feasible, enabling the provision of training courses, equipment, warehouses for screening, and transport to the recycling site.

\subsubsection{Overview of the sanitary landfill in the municipality of Ariquemes (RO)}

The Ariquemes sanitary landfill, which has been in operation since 2012, has an expected lifetime of 14 years and the capacity to receive $150 \mathrm{t} \mathrm{day}^{-1}$ of MSW.

The sanitary landfill is $7 \mathrm{~km}$ from the urban area of Ariquemes and its main access is along a paved road. The landfill received $135 \mathrm{t} \mathrm{day}^{-1}$ of MSW generated by 354,196 inhabitants from 14 municipalities of Rondônia State, in 2018.

These municipalities are distributed at an average distance of approximately $95 \mathrm{~km}$ from the landfill, which it is managed by the Inter-municipal Sanitation Consortium of the Central Region of Rondonia [33]. 
At the design stage of the Ariquemes landfill, it was envisaged that there would be the construction and operation of sorting and composting units, as well as rubble and PET waste processing units [33]. However, the sorting has not been performed, so all types of wastes are deposited in the landfill, affecting its lifetime.

The landfill area incorporates a biological slurry treatment system with capacity based on the average rainfall of the region, which reaches $2,100 \mathrm{~mm}$ per year. This system includes an anaerobic lagoon, a facultative lagoon, a maturation lagoon, and subsequent discharge into the receiving body. However, the treatment system did not possess a flow meter, so control was performed in an empirical way. In 2016, the lagoons overflowed due to intense rainfall, demonstrating the vulnerability of sanitation facilities in the Amazon environment.

The operational cost of the landfill is around US\$ 44,000 per month (including maintenance, labor, fuel, and energy consumption), while the MSW transport cost is US\$ $0.07(\mathrm{t} \mathrm{km})^{-1}$, corresponding to an average of US\$27,600 per month, with both costs being proportionally split among the municipalities of the consortium [33].

It can be seen that the main problems of the landfills located in the Amazon region include the difficulties involved in transporting and compacting the wastes, as well as problems in operating effluent treatment systems, especially during the rainy season. Another important issue that should be highlighted is the lack of economic value and markets for various wastes that could be recycled, which if resolved would increase the lifetimes of landfills, while at the same time providing economic and social benefits.

\subsection{MSW management options in the Amazon: gaps and challenges}

MSW management, whether in Brazil or in other countries of Europe, Asia, Latin America, and North America, generally incorporates the following operations: collection, separation, treatment (recycling, incineration, composting, and anaerobic digestion), and final disposal (sanitary landfill). In Brazil, the NPSW highlights the need to reduce MSW generation, necessitating the implementation of environmental education programs or other actions involving the population [1], [2].

Recycling, which is also emphasized in the NPSW, is poorly developed in the Amazon, due to the lack of integration of the informal recycling sector in the formal system, lack of support from the municipal authorities, and concentration of the recycling companies in the capitals and metropolitan regions [2]. The recycling sector is most developed in the South and Southeast regions of Brazil, where 56\% of the population lives [23].

The use of composting, one of the most recommended techniques for the treatment of organic wastes, is limited in Brazil generally, but especially in the Amazon. This can be largely explained by the inadequate separation of the MSW fractions, due to the maintenance and operation limitations in regions of high rainfall, lack of investment, and the difficulty of society to absorb the compost generated [34].

The use of incineration, which greatly reduces the volume and mass of MSW, is widely adopted in Europe and the United States. However, it has a high investment cost and requires a high daily quantity of MSW for the purpose of harnessing energy (over 50 t.day $^{-1}$ ) [1]. These requirements limit its use in the Amazon, due to the low generation of MSW and the poor economic conditions of the municipalities.

In the Brazilian context, the disposal of MSW in landfills can be highlighted, although there still are many municipalities, mainly of small size (fewer than 20,000 inhabitants), that do not have the necessary resources for landfill construction, leading to the proliferation of dumps. In order to change this scenario, it will be essential to encourage inter-municipality cooperation, as well as to stimulate the creation of local cooperatives and associations [34]. 
Table 2 summarizes the main challenges for MSW management in the Southwest Brazilian Amazon, showing the existing gaps and suggesting strategic actions.

Table 2: Problems, gaps, and options for MSW management in the Southwest Brazilian Amazon region.

\begin{tabular}{|c|c|c|}
\hline Problems & Gaps & Options \\
\hline $\begin{array}{l}\text { Environmental } \\
\text { and sanitation } \\
\text { impacts of } \\
\text { dumps. }\end{array}$ & $\begin{array}{l}\text { Lack of } \\
\text { landfills }\end{array}$ & $\begin{array}{l}\text { Construction of small size landfills, with } \\
\text { capacity for MSW disposal of up to } 20 \mathrm{t}^{-1} \mathrm{da}^{-1} \text {, in } \\
\text { municipalities with up to } 30,000 \text { inhabitants. }\end{array}$ \\
\hline $\begin{array}{l}\text { Lack of adequate } \\
\text { road transport. }\end{array}$ & $\begin{array}{l}\text { Recyclable } \\
\text { materials } \\
\text { logistics. }\end{array}$ & $\begin{array}{l}\text { Structure the river transport of recyclable } \\
\text { materials up to the city of Manaus, considering a } \\
\text { collection route including the municipalities } \\
\text { along the Madeira River (Humaitá, Manicoré, } \\
\text { Novo Aripuanã, Borba, and Nova Olinda). }\end{array}$ \\
\hline $\begin{array}{l}\text { Population } \\
\text { involvement; } \\
\text { diffuse waste. }\end{array}$ & $\begin{array}{l}\text { Environmental } \\
\text { education } \\
\text { actions. }\end{array}$ & $\begin{array}{l}\text { Environmental education programs related to } \\
\text { sustainable MSW management and supported by } \\
\text { the local city mayors. Home composting for } \\
\text { further use in urban and peri-urban agriculture. }\end{array}$ \\
\hline $\begin{array}{l}\text { Low generation } \\
\text { of recyclable } \\
\text { materials; low } \\
\text { population } \\
\text { density. }\end{array}$ & $\begin{array}{l}\text { Develop the } \\
\text { market for } \\
\text { recyclable } \\
\text { materials in } \\
\text { the region. }\end{array}$ & $\begin{array}{l}\text { Update of the Municipal Plan for Integrated } \\
\text { MSW Management. Implementation of recycling } \\
\text { industries in this region by means of partnerships } \\
\text { between the municipal and State authorities and } \\
\text { the productive sector. Promotion of waterway } \\
\text { logistics. Promotion of the economic } \\
\text { sustainability of cooperatives and associations. }\end{array}$ \\
\hline Poor supervision. & $\begin{array}{l}\text { Structural } \\
\text { deficiencies. }\end{array}$ & $\begin{array}{l}\text { Structuring of municipal services with actions to } \\
\text { improve the management of functions, service } \\
\text { supervision, implementation of information } \\
\text { tools, and elaboration of projects to promote } \\
\text { resources in notices of the Ministry of } \\
\text { Environment and Cities. }\end{array}$ \\
\hline $\begin{array}{l}\text { MSW collection; } \\
\text { organic wastes; } \\
\text { low demand for } \\
\text { organic material; } \\
\text { rainfall in the } \\
\text { Amazon. }\end{array}$ & $\begin{array}{l}\text { Sorting of } \\
\text { recyclable } \\
\text { materials. } \\
\text { Lack of } \\
\text { composting } \\
\text { programs. }\end{array}$ & $\begin{array}{l}\text { Implement strategic points for voluntary } \\
\text { collection of recyclable materials at large size } \\
\text { supermarkets. Raise public awareness regarding } \\
\text { the need to reduce organic wastes. Make } \\
\text { warehouses available for the installation of } \\
\text { composters. }\end{array}$ \\
\hline $\begin{array}{l}\text { Presence of } \\
\text { pickers at dumps. }\end{array}$ & $\begin{array}{l}\text { Cooperatives } \\
\text { in the Humaitá } \\
\text { region. }\end{array}$ & $\begin{array}{l}\text { Support collectors to enable them to organize } \\
\text { themselves in associations or cooperatives, with } \\
\text { technical support to search for financing to } \\
\text { subsidize the acquisition of equipment and } \\
\text { materials. Promote the social inclusion of } \\
\text { collectors, considering social policies. Create } \\
\text { incentives for the adhesion of collectors in } \\
\text { cooperatives. }\end{array}$ \\
\hline
\end{tabular}




\section{CONCLUSIONS}

The findings of this work revealed a scarcity of peer-reviewed scientific articles concerning municipal solid waste management in the Amazon. The issues leading to unsatisfactory MSW management in this region are complex, although a number of strategies for improving the existing systems in the Southwest Brazilian Amazon were identified, which could be extended to the other countries of the Amazon. These strategies include ongoing investment in environmental education and awareness programs, reduced generation of MSW, and the creation and implementation of statutory instruments. Furthermore, there is the need for investment in treatment technologies, together with strengthening of the recycling and composting chain, involving selective collection, and greater inclusion of waste collectors in the municipal solid waste management system.

\section{REFERENCES}

[1] Paes, M.X. et al., Life cycle assessment as a diagnostic and planning tool for waste management: A case study in a Brazilian municipality. Journal of Solid Waste Technology and Management, 44, pp. 259-269, 2018.

[2] Oliveira, B.O.S. \& Medeiros, G.A., Evolution and challenges in the management of urban solid waste in the states of North region, Brazil. Revista Valore, 4, pp. 749-761, 2019.

[3] Dalagnol, R., Borma, L.S., Mateus, P. \& Rodriguez, D.A., Assessment of climate change impacts on water resources of the Purus Basin in the southwestern Amazon. Acta Amazonica, 47(3), pp. 213-226, 2017.

[4] Monteiro, K.F.G., Contribuições para a gestão ambiental da cadeia produtiva de biodiesel na Amazônia Brasileira e Colombiana. Oecologia Australis, 15(2), pp. 351$364,2011$.

[5] Instituto Brasileiro de Geografia e Estatística, Panorama do município de Humaitá. https://cidades.ibge.gov.br/brasil/am/humaita/panorama. Accessed on: 31 Aug. 2019.

[6] Instituto Brasileiro de Geografia e Estatística, Panorama do município de Manicoré. https://cidades.ibge.gov.br/brasil/am/manicoré/panorama. Accessed on: 31 Aug. 2019.

[7] Instituto Brasileiro de Geografia e Estatística, Panorama do município de Ariquemes. https://cidades.ibge.gov.br/brasil/ro/ariquemes/panorama. Accessed on: 31 Aug. 2019.

[8] Vieira, N.M.C. et al., Managing the technology for selectively collecting solid waste in the western Amazon sub region. Journal of Solid Waste Technology and Management, 44(1), pp. 44-51, 2018.

[9] Oliveira, B.O.S., Tucci, C.A.F., Neves Júnior, A.F. \& Santos, A.A., Avaliação dos solos e das águas nas áreas de influência de disposição de resíduos sólidos urbanos de Humaitá, Amazonas. Revista Engenharia Sanitária e Ambiental, 21(3), pp. 593-601, 2016.

[10] Castro, M.A.O. et al., Developing indicators for sustainable management of solid waste in Iranduba, Manacapuru and Novo Airão municipalities, Amazon, Brazil. Revista Engenharia Sanitária e Ambiental, 20(3), pp. 415-426, 2015.

[11] Souza, S.N.M. et al., Technical potential of electricity production from municipal solid waste disposed in the biggest cities in Brazil: Landfill gas, biogas and thermal treatment. Waste Management \& Research, 32(10), pp. 1015-1023, 2014.

[12] Bernardes, C. \& Gunther, W.M.R., Generation of domestic solid waste in rural areas: case study of remote communities in the Brazilian Amazon. Human Ecology, 42, pp. 617-623, 2014. 
[13] Matos, F.B., Camacho, J.R., Rodrigues, P. \& Guimarães Jr., S.C.A., Research on the use of energy resources in the Amazon. Renewable and Sustainable Energy Reviews, 15, pp. 3196-3206, 2011.

[14] Silva, A.D. \& Pinheiro, E.S., A problemática dos resíduos sólidos urbanos em Tefé, Amazonas. Sociedade \& Natureza, 22(2), pp. 297-302, 2010.

[15] Pavani, I.D. et al., Allocation of sanitary landfill in consortium: Strategy for the Brazilian municipalities in the State of Amazonas. Environmental Monitoring and Assessment, 191(39), pp. 1-13, 2019.

[16] Mendes, A. et al., Relations of the groundwater quality and disorderly occupation in an Amazon low-income neighborhood developed over a former dump area, Santarém/PA, Brazil. Environment, Development and Sustainability, 21, pp. 353-368, 2019.

[17] Imbiriba, B.C.O. et al., Estimates of methane emissions and comparison with gas mass burned in CDM action in a large landfill in Eastern Amazon. Waste Management, 101, pp. 28-34, 2020.

[18] Gauthier, C. \& Moran, E.F., Public policy implementation and basic sanitation issues associated with hydroelectric projects in the Brazilian Amazon: Altamira and the Belo Monte dam. Geoforum, 97, pp. 10-21, 2018.

[19] Criollo, R., Malheiros, T. \& Alfaro, J.F., Municipal environmental management indicators: A bottom-up approach applied to the Colombian context. Social Indicators Research, 141, pp. 1037-1054, 2019.

[20] Colorado-Lopera, D., Echeverry-Lopera, G. \& Colorado-Lopera, H.A., Logistics as an essential area for the development of the solid waste management in Colombia. Informador Técnico, 83(2), pp. 131-154, 2019.

[21] Ziegler-Rodriguez, K. et al., Transitioning from open dumpsters to landfilling in Peru: Environmental benefits and challenges from a life-cycle perspective. Journal of Cleaner Production, 229, pp. 989-1003, 2019.

[22] Larsen, P.B., Municipal environmental governance in the Peruvian Amazon: A case study in local matters of (in)significance. Management of Environmental Quality, 22(3), pp. 374-385, 2011.

[23] Ministério das Cidades (MCIDADES), Sistema nacional de informações em saneamento básico: Diagnóstico do manejo de resíduos sólidos. MCIDADES, p. 188, 2018.

[24] Ministério de Medio Ambiente y Agua (MMAyA), Diagnóstico de la gestión de resíduos sólidos en Bolívia. MMAyA, p. 355, 2011.

[25] Superintendencia de Servicios Públicos Domiciliários (SSPD), Disposición final de residuos sólidos. SSPD, p. 78, 2017.

[26] Instituto Nacional de Estatística e Censos do Equador (INEC), Censo de información ambiental económica en gobiernos autónomos descentralizados provinciales. INEC, p. 14, 2018.

[27] Ministry of Local Government and Regional Development (MLGRD), Putting waste in its place: a national solid waste management strategy for the Cooperative Republic of Guyana 2013-2024. Ministry of Communities, p. 49, 2016.

[28] Ministério del Ambiente (MINAM), Plan nacional de gestión integral de residuos sólidos. MINAM, p. 89, 2016.

[29] Instituto Nacional de Estadística (INE), Generación y manejo de residuos y desechos sólidos en Venezuela, 2011-2012. INE, p. 18, 2013.

[30] Inter-American Development Bank (IDB), Sustainability report - 2016. IDB, p. 55, 2017. 
20 Environmental Impact V

[31] Quinhões, R.C., Territorial development and Amazon integration: a new management perspective on the tri-border between Peru, Brazil and Bolivia. Athens Journal of Tourism, 3(1), pp. 53-74, 2016.

[32] Guimarães, M.A., Lixo: Uma Abordagem Teórico-Prática, Edua: Manaus, p. 327, 2014.

[33] Consórcio Intermunicipal de Saneamento da Região Central de Rondônia (CISAN), Relatório de Impacto Ambiental: Ampliação da capacidade do aterro sanitário de Ariquemes. CISAN, p. 73, 2016.

[34] Deus, R.M., Battistelle, R.A.G. \& Silva, G.H.R., Scenario evaluation for the management of household solid waste in small Brazilian municipalities. Clean Technologies and Environmental Policy, 19, pp. 205-214, 2017. 